\title{
CIVILIAN JUDGES AND MILITARY JUSTICE: COLLATERAL REVIEW OF COURT-MARTIAL CONVICTIONS
}

\author{
JOSEPH W. BISHOP, JR.*
}

Generals Mercier and Boisdeffre ..... made the fatal error of standing on the principle that Army justice was, like the Army itself, a thing apart, and that civilian conceptions of justice had no weight before a military tribunal. . . .

From this it will be seen that in reality the question of Alfred Dreyfus's guilt or innocence is minor to the far wider question of the position of the Army in a democratic State. No Republican could for a moment accept the claim that the principles of justice were not identical, whatever the tribunal and whatever the procedure. ${ }^{1}$

\section{The Nature and Practical Significance of the Problem}

On a night in March 1945, as the Third Reich was crumbling into spectacular ruin, two buck privates from an American Tank Destroyer Battalion were sent into the town of Langenlonsheim to look for a missing comrade. In the town some fifty or sixty civilians had that night taken shelter in a cellar from artillery fire. Three women among them were raped by two men in American uniform. They made complaint, and the next morning the two soldiers, Privates Arnold and Anthony, were arrested. Their identification by the witnesses seems to have been a good deal less than conclusive, ${ }^{2}$ so much less so that the officer conducting the pretrial investigation required by the seventieth Article of $\mathrm{War}^{3}$ recommended that the charges against the two be dropped. The Staff Judge Advocate being of other opinion, the pair were tried jointly by general court-martial on April 3. The appointed defense counsel was a medical officer, innocent of previous experience of courts, martial or otherwise. The accused requested a number of combat soldiers as witnesses, but the Army had advanced far and fast in the interim, these combat soldiers had no fixed abode, and the trial was held at a place about 100 miles east of Langenlonsheim. The upshot was that none of the witnesses requested by the accused was made available. It is possible to infer that whatever search was made for them was neither very thorough nor very persistent. Both Arnold and Anthony

* Professor of Law, Yale Law School.

1. Chapman, The French Army and Politics, in Soldrers aNd Governments 51, 62 (Howard ed. 1957). The word "Republican" is, of course, employed in the French sense.

2. The facts of the case are set forth at some length in the opinion in Anthony v. Hunter, 71 F. Supp. 823 (D. Kan. 1947). "Most" of the witnesses identified Arnold, and "approximately half" identificd Anthony; some were unable to identify either, and some identified other soldiers in a lineup. The complaining witnesses who identified Anthony had originally described their assailant as having a mustache. Anthony offered to produce witnesses to show that he had never worn a mustache, but in the confusion incident to the headlong pursuit of the disintegrating Wchrmacht, none of these witnesses was located by the military authorities.

3. Act of June 4, 1920, ch. 227, \& 1, 41 Stat. 802, as amended, 50 Stat. 724 (1937). 
were found guilty and sentenced to death. The findings and sentences were duly approved by the military reviewing authorities, although the sentences were reduced first to life imprisonment and then to thirty-five years confinement at hard labor-still a longish time to serve, even for a young man. Anthony was sent to the United States Penitentiary at Leavenworth, Kansas, Arnold to the United States Correctional Reformatory at Seagoville, Texas-a happenstance that was to have major consequences.

In 1947, Anthony petitioned the United States District Court for the District of Kansas for a writ of habeas corpus, alleging in substance that the court-martial was without jurisdiction because the mandatory pretrial investigation was neither adequate nor impartial and because he had been denied due process of law by a "totality of errors," including the incompetence, however excusable, of his appointed counsel, denial of counsel of his own choice, failure to obtain the witnesses he had requested, and the failure of the reviewing authority to set the conviction aside for insufficiency of evidence. He produced the investigating officer, who had returned to civilian life, and the latter's testimony convinced the court that the pretrial investigation had in fact fallen short of the requirements of Article of War 70, which the court held to be jurisdictional. On this ground the writ was granted, and Anthony went free. ${ }^{4}$ But Anthony's other contentions were by no means rejected; although the judge chose to rest his holding on the defects in the pretrial investigation, he added that the inadequacies of the trial itself "individually and collectively might have justified this court in plagiarizing some of the language used by Judge Biggs . . . in Hicks v. Hiatt ...." Since Hicks v. Hiatt ${ }^{6}$ was a case in which Judge Biggs, a senior circuit judge sitting as a district judge, had granted a writ of habeas corpus to a soldier convicted by general court-martial on the stated ground that the accumulation of errors at the trial-notably in the admission and exclusion of evidence-was so gross that the "procedures of the military law were not applied to Hicks in a fundamentally fair way,"7 the reference to that decision made plain the sentiments of the Kansas dis-

4. Anthony v. Hunter, 71 F. Supp. 823 (D. Kan. 1947). The court left open the question whether it thought that the failure to comply with Article of War 70 deprived the court-martial of its jurisdiction because Congress had made such compliance a condition precedent to the exercise of court-martial jurisdiction or because the lack of adequate and impartial investigation denied petitioner the due process "contemplated by organic law," by which the court presumably meant the fifth amendment to the Constitution. The result would, of course, be the same under either theory. Id. at 831 ; see Pasley, The Federal Courts Look at the Court-Martial, 12 U. PIrT. L. REv. 7, 17 (1950).

5. 71 F. Supp. at 831.

6. 64 F. Supp. 238 (M.D. Pa. 1946).

7. Id. at 250 . There was no appeal in the Hicks case because the proceedings had been rendered moot by the military authorities' exercise of clemency. Id. at 250 n.28; see Pasley, supra note 4, at 29 . The Government's brief in the Anthony case described Hicks v. Hiatt as "an unfortunate legal accident." See Anthony v. Hunter, 71 F. Supp. 823, 828 n.4 (D. Kan. 1947). 
trict court. The Government did not appeal. The reasons for its acceptance of the result are conjectural; but almost certainly those reasons did not include agreement with the actual ground of the decision-the proposition that failure to comply with Article of War 70 deprived the court-martial of jurisdiction-for less than two years later the Government litigated that issue to a successful conclusion in the Supreme Court. ${ }^{8}$ It may be guessed, therefore, that the Army and the Department of Justice suspected that, on the somewhat unappealing facts of the case, a Court of Appeals would be tempted to affirm on the ground that the trial had been so unfair as to amount to a denial of due process.

A few months later, Anthony's coaccused, Arnold, tried his luck in the District Court for the Northern District of Texas, within whose jurisdiction Seagoville is located. That court deemed the problem so simple and the merits of the case so irrelevant-the entire opinion runs to fewer than 500 words-that it did not bother to state the grounds of Arnold's petition, ${ }^{0}$ which it summarily denied. ${ }^{10}$ The bases, emotional and legal, of the Texas district judge's holding cannot be better summarized than in his own words:

During this time that the alleged offense was committed and the court-martial held, actual warfare was in progress. The Army was on the forward move. Bullets were flying. Those who gathered the witnesses, as well those who came and went, were in the firing zone of attacking snipers, as well as the other dangers and eventualities of active warfare.

The court-martial was properly convened. It had jurisdiction of the offense and of the parties. The sentence was within the law. Those facts being irrefutably established, the civil court may not inquire further. Hurse v. Caffey ....11

So Arnold stayed in prison while Anthony went free. ${ }^{12}$

8. Humphrey v. Smith, 336 U.S. 695 (1949). Article 32 of the present Uniform Code of Military Justice provides explicitly that a failure to comply with its requirement of thorough and impartial pretrial investigation shall not constitute "jurisdictional error." 10 U.S.C. \& 832 (1958).

9. From the facts that Arnold and Anthony had been tried in common, with the same medical officer as defense counsel, that the same lawyer handled their petitions for habeas corpus, and that the former investigating officer testified at Arnold's hearing as he had at Anthony's, we are tolerably safe in inferring that the allegations were about the same as in the earlier ease.

10. Arnold v. Cozart, 75 F. Supp. 47 (N.D. Tex. 1948). I do not know the subsequent fate of Private Arnold. If, as may be conjectured, the reasons for the Government's failure to appeal in the case of Private Anthony lay in its doubts about the merits of the case, Arnold may have received clemency. If he is still in jail, one can hope that the monotony of his confinement is ameliorated by the receipt of an occasional posteard from Private Anthony.

11. $75 \mathrm{~F}$. Supp. at 48. The court's reasons for citing Hurse v. Caffey, $59 \mathrm{~F}$. Supp. 363 (N.D. Tex. 1945) are not readily apparent. That case involved a collateral attack upon a court-martial sentence by way of habeas corpus, but there the resemblance ends. Hurse claimed no denial of constitutional due process, but only that the record failed to show that the death penalty had, as required by the Articles of War, been voted by all of the members of the court then present. The district court's holding seems to have been merely that, pending measures by the military to correct the defect in the record, the petition was premature.

12. This result is unfortunately not unique. Compare Jackson v. Taylor, 353 U.S. 
Whatever this was, it was not even-handed justice, for Arnold and Anthony had had an equally fair or unfair trial. ${ }^{13}$ If one belonged behind bars, so did the other; if one had a constitutional right to liberty, so had the other. Nor do the results of the two cases reflect a mere difference in two district judges' personal appraisals of the fairness of the particular court-martial. What these two decisions do is to place in stark contrast two basic approaches to the problem of collateral review of military justice-a problem which has bedeviled the lower federal courts since World War II and one which the Supreme Court has so far conspicuously failed to resolve. Although a number of cases postdating World War II have raised the problem, in most of them the Court, or some faction of the Court, has employed language which can be and has been quoted to support both the position that the proper scope of the federal courts' review of military justice is limited to a mechanical testing for the bare essentials of jurisdiction over person and offense, and the power to impose the sentence--what Justices Douglas and Black call "'jurisdiction' in the historic sense"14 and the position that such review should approximate in breadth and depth modern collateral review of the proceedings of civil courts in criminal cases, including examination to see whether the court, though originally possessing jurisdiction over the person and the offense, has lost it by unfairness amounting to a denial of constitutional due process. The Supreme Court cases, in fact, leave the reader with a strong impression that the Justices have been, and probably still are, no more harmonious among themselves than the lower federal judges and, indeed, that some of them have yet to make up their own minds.

\section{The History of the Problem}

Prior to 1944 or thereabouts there was a nearly monolithic harmony within and beneath the Supreme Court. Nothing was better settled than the proposition that the federal courts, having no appellate jurisdiction over military tribunals, ${ }^{15}$ would, in collateral proceedings attacking the validity

569 (1957), with De Coster v. Madigan, 223 F.2d 906 (7th Cir. 1955). The Government filed no petition for certiorari in the latter case, with the result that De Coster went free while his coaccused stayed in jail.

13. There is some suggestion that the evidence against Arnold was stronger than that against Anthony. See note 2 supra. But since it seems clear that the two were together at the time they were alleged to have committed the offense, the identification of one would necessarily at least place the other at the locus delicti. In any case, the strength of the evidence was not-at least in theory and in the circumstances of these cases-directly relevant to the question of the court-martial's jurisdiction.

14. See Burns v. Wilson, 346 U.S. 137, 152 (dissenting opinion), rehearing denied, 346 U.S. 844 (1953).

15. E.g., In re Yamashita, 327 U.S. 1, 8 (1946); In re Vidal, 179 U.S. 126 (1900); Ex parte Vallandigham, 68 U.S. (1 Wall.) 243 (1864); Dynes v. Hoover, 61 U.S. (20 How.) 65, 81 (1858); Shaw v. United States, 209 F.2d 811 (D.C. Cir. 1954); see E.x parte Mason, 105 U.S. 696, 697 (1881); WintHrop, MILITARy LaW and Precedents 50-54 (2d ed. 1920). 
of a military sentence, most strictly limit themselves to "ascertaining whether the military court had jurisdiction of the person and subject-matter, and whether ... it had exceeded its powers in the sentence pronounced."10 " $[N] 0$ mere errors in their proceedings are open to consideration. The single inquiry, the test, is jurisdiction."17 Nor were these rescripts merely sweeping language gratuitously employed in the decision of easy cases. Consider, for example, Keyes $v$. United States, ${ }^{18}$ a suit by a cashiered second lieutenant in the 5th Cavalry to collect his pay, on the ground that the court-martial sentence dismissing him from the service was invalid. The "mere errors" in that case, as found by the Court of Claims, included the facts that the colonel commanding the regiment had preferred one of the charges, had appeared as a prosecution witness, and, sitting as a member of the court-martial, had voted on the finding and sentence. The Supreme Court affirmed the dismissal of Keyes's petition on the uncomplicated ground that, since "the court-martial . . . had cognizance of the charges made, and had jurisdiction of the person of the appellant .... whatever irregularities or errors are alleged to have occurred in the proceedings, the sentence of dismissal must be held valid when it is questioned in this collateral way."10 Even ex-Captain Oberlin Carter, probably as pertinacious a long-distance litigant as is to be found in the legal annals of the United States, could find no chink or cranny in the wall, though he devoted nearly forty years of indefatigable and almost monomaniac effort to attempts to secure the nullification of his court-martial sentence, and ended by alleging nothing less than personal prejudice on the part of the Assistant Judge Advocate General and the members of the court-martial, intimidation of defense witnesses, abstraction of defense documentary evidence, use by the prosecution of evidence known by it to be false, and sundry other irregularities which, if they really occurred (and no court ever decided that they did not), would certainly seem to have given the proceedings some tincture of unfairness. He never won a round. ${ }^{20}$

16. Carter v. Roberts, 177 U.S. 496, 498 (1900). This language was quoted with approval in Carter v. McClaughry, 183 U.S. 365, 380 (1902), in which Mr. Chief Justice Fuller eulogized the proposition as "the salutary rule that the sentences of courts martial, when affirmed by the military tribunal of last resort, cannot be revised by the civil courts save only when void because of an absolute want of power, and not merely voidable because of the defective exercise of power possessed." Id. at 401.

17. In re Grimley, 137 U.S. 147, 150 (1890); see Collins v. McDonald, 258 U.S. 416 (1922); Winthrop, Military LaW and Precedents 52-53 (2d ed. 1920). These talismanic sentences are cited with particular frequency in subsequent cases. The Mamlal for Courts-Martial, which favors the orthodox view, quotes them. See MANUAL For Courts-Martial Únited States \I 214C (1951).

18. 109 U.S. 336 (1883).

19. Id. at 340 . Such language still finds echoes in modern courts. See Moses y. United States, $137 \mathrm{Ct}$. Cl. 374, 380 (1957) ("It is well settled that this court, regardless of any errors that may have been committed, cannot grant relief from the consequences of a court-martial sentence if the court-martial had jurisdiction of the case."). 20. In re Carter, 97 Fed. 496 (C.C.S.D.N.X. 1899), aff'd sibb nom. Rose ext rel. Carter 
The Second World War saw armies of a size unprecedented in the history of the United States and, as a necessary corollary, courts-martial in numbers theretofore unimaginable. Despite large scale post-war clemency, ${ }^{21}$ there remained in federal penal institutions a great number of men who were there pursuant to sentences of Army or Navy courts-martial. ${ }^{22}$ Being no more anxious to stay in jail than their civilian counterparts, they presently took to the courts by squads and platoons. Few of the petitioners could adduce the orthodox grounds of collateral attack, for in practically every case it was plain that the court-martial had had jurisdiction over the person and the offense and power to impose the sentence; but it was inevitable, given the frequently amateur personnel of wartime courts-martial and the stresses and strains under which they operated, especially overseas, that some of the petitioners could tell startling, and sometimes apparently truthful, tales of unfairness, calculated to cause a federal judge of average fairmindedness to chafe under the restrictions of the traditional rules and make him receptive to the heterodox proposition that even soldiers were entitled to some sort of due process, whether by virtue of the Constitution or the Articles of War, the denial of which could cause a court-martial to lose the jurisdiction that it would otherwise have had. Mention has been made of the Hicks case; another circuit judge siting as a district judge detonated with an explosion still more ear-shattering. Starting with the mild observation that "the trial ... in the eyes of both the prosecution and the defense was wholly obnoxious and repulsive to their fundamental sense of justice," Judge Murrah had "no difficulty in finding that the court which tried this man was saturated with tyranny; the compliance with the Articles of War and with military justice was an empty and farcical compliance only. . .."23 The petitioner went free, at least temporarily. ${ }^{24}$ There were a number of

v. Roberts, 99 Fed. 948 (2d Cir.), cert. denied, 176 U.S. 684, appeal dismissed, 177 U.S. $496(1900)$; Carter v. McClaughry, 105 Fed. 614 (C.C.D. Kan. 1900), aff'd, 183 U.S. 365 (1902); Carter v. Woodring, 92 F.2d 544 (D.C. Cir.), cert. denied, 302 U.S. 752 (1937); see Burns v. Wilson, 346 U.S. 844, 846 (1953) (separate opinion of Mr. Justice Frankfurter).

21. It was estimated that the Clemency Board established by the War Department after World War II would examine about 30,000 cases out of a total of 90,000 wartime convictions by general courts-martial of the Army, the remainder of those convicted being restored to duty through the Army's rehabilitation program. See Note, 57 YALE L.J. 483, 488 \& n.39 (1948).

22. As of the end of 1945 , this prison population numbered nearly 40,000 , more than a thirty-fold increase since 1940. See U.S. Bureau of the Census, Prisoners in State and Federal Prisons and Reformatories 103 (1946).

23. Beets v. Hunter, 75 F. Supp. 825, 826 (D. Kan. 1948). The opinion was obviously delivered on the spot, orally, and at white heat.

24. The subsequent history of the Beets case was somewhat anticlimactic. After the writ had been granted and before the appeal was heard, Congress amended the 53d Article of War to permit application to the Judge Advocate General for vacation of sentence or new trial. Selective Service Act of 1948, ch. 625, \& 230, 62 Stat. 639. The Court of Appeals reversed on the ground that Beets was required to exhaust his newly granted administrative remedy before seeking collateral review. Hunter v. Beets, 180 F.2d 101 (10th Cir.), cert. denied, 339 U.S. 963 (1950). Again, I do not know the 
other cases in which inferior federal courts undertook to conduct a searching collateral review of allegedly unfair proceedings of courts-martial, ${ }^{25}$ though in all probability none of them got up quite as great a head of steam as Judge Murrah. ${ }^{26}$

Despite these mutterings, and even roars, of discontent among the judicial proletariat, the Supreme Court was far from ready to open the safety valve; indeed, it has not to this day allowed a military prisoner to be freed because of unfairness in his trial. In Humphrey $v$. Smith, 2r the petitioner sought to impeach a court-martial verdict not only on the ground (as in the Anthony case) that inadequate pretrial investigation deprived the court-martial of jurisdiction, but on the further ground that the incompetence of his counsel and errors in the admission of evidence had had that effect. The District Court, although disclaiming any intent to examine the record for error, did in fact review it carefully and found no merit in any of the contentions. ${ }^{28}$ Basing its decision solely on the inadequacy of the pretrial investigation, the Court of Appeals ordered the writ granted.20 Mr. Justice Black and five of his brethren, reversing on the ground that the requirement of pretrial investigation was not jurisdictional, nevertheless went out of their way "at once [to] dispose of" petitioner's other contentions, ${ }^{30}$ citing those most orthodox of orthodox decisions, Carter $v$. McClanghry and In re Yamashita. Yet a close observer might have discerned that the door was not quite closed, for Mr. Justice Black, perhaps casually and perhaps with meticulous care, limited the holding to a "courtmartial conviction resulting from a trial fairly conducted"31_a qualification which, however cautious, had not been adumbrated by anything in the language of earlier opinions. Moreover, although Smith's contentions went not only to the alleged absence of evidence sufficient to support his conviction but also to the alleged unfairness of his trial, all that Mr. Justice Black actually said was that, while the evidence "was in sharp dispute, ... our authority in habeas corpus proceedings to review court-martial judg-

ultimate fate of the petitioner; his name appears no more in the reports, from which it may perhaps be inferred that the administrative remedy was effective.

25. E.g., Hiatt v. Brown, 175 F.2d 273 (5th Cir. 1949), rev'd, 339 U.S. 103 (1950); U.S. ex rel. Innes v. Hiatt, 141 F.2d 664, 666 (3d Cir. 1944); see Kuykendall v. Hunter, 187 F.2d 545, 546 (10th Cir. 1951). For an excellent analysis and evaluation of the cases decided prior to 1950 see Pasley, supra note 4. See also Note, Collateral Attack on CourtsMartial in the Federal Courts, 57 YALE L.J. 483 (1948).

26. Compare, however, Shapiro v. United States, 69 F. Supp. 205, 207 (Ct. C1. 1947) ("flagrant case of military despotism. ... verdict... evidently rendered in spite against a junior officer who had dared to demonstrate the fallibility of the judgment of his superior officers ..... almost complete denial of plaintiff's constitutional rights").

27. 336 U.S. 695 (1949).

28. See Ex parte Smith, 72 F. Supp. 935,937 (M.D. Pa. 1947).

29. Smith v. Hiatt, 170 F.2d 61 (3d Cir. 1948).

30. 336 U.S. at 696 . The three dissenting Justices, Murphy, Douglas, and Rutledge, confined their dissent to the pretrial investigation question. Id. at 701 .

31. Id. at 701. 
ments does not permit us to pass on the guilt or innocence of persons convicted by courts-martial'32 - a proposition which, assuming the presence of some evidence to support the finding, is unlikely to be disputed by many lawyers, military or civilian. Finally, perusal of the district court's review of the record leaves one pretty well persuaded that Smith was guilty, a circumstance which in practice may not be altogether irrelevant; none of the Justices could have lost much sleep over the hardness of his case. Thus the Smith case afforded no reliable basis for prophecy about what would happen if a really hard case reached the Court. In a case decided the same day the Court refused to exclude the possibility that at least the double jeopardy provision of the fifth amendment was applicable to court-martial proceedings, though it found that the petitioner had not in fact been put twice in jeopardy within the intent of that amendment. ${ }^{33}$

What seemed to a district court and a court of appeals a sufficiently hard case did in fact reach the Court the following year-a case in which the lower courts had directed the petitioner's release because the record was so "replete with highly prejudicial errors and irregularities" as to amount to a denial of due process in violation of the fifth amendment. ${ }^{34}$ The Supreme Court unanimously ${ }^{35}$ reversed and did so in terms calculated sharply to remind the errant lower courts of their limited function in military habeas corpus proceedings:

We think the court was in error in extending its review, for the purpose of determining compliance with the due process clause, to such matters as the propositions of law set forth in the staff judge advocate's report, the sufficiency of the evidence to sustain respondent's conviction, the adequacy of the pretrial investigation, and the competence of the law member and defense counsel. . . . "The single inquiry, the test, is jurisdiction." In re Grimley ... the correction of any errors [the court-martial] may have committed is for the military authorities which are alone authorized to review its decision. ${ }^{36}$

Nevertheless, it would strain an ordinarily conscientious court to ignore such errors as were found by the court of appeals in the Brown case; those errors included conviction of murder on "evidence that does not measure to malice, premeditation, or deliberation," incompetence and lack of preparation of appointed defense counsel, "gross" incompetence of the court's law member, and "total misconception of the applicable law" by the military

32. Id. at 696.

33. Wade v. Hunter, 336 U.S. 684 (1949). Again Mr. Justice Black wrote for the majority. The three dissenters, who thought Wade was put twice in jeopardy, stated flatly, as they had to, that Wade, though a soldier, had rights under the fifth amendment the denial of which was a proper subject of collateral review. Id. at 692, 694. See text accompanying notes 74,77 infra.

34. Hiatt v. Brown, 175 F.2d 273, 277 (5th Cir. 1949), rev'd, 339 U.S. 103 (1950).

35. Mr. Justice Douglas did not participate.

36. Hiatt v. Brown, 339 U.S. 103, 110 (1950). 
reviewing authorities. ${ }^{37}$ Had the proceedings been concerned with a conviction by a civil court, such findings would certainly have presented a substantial question of denial of due process. ${ }^{38}$

If the Brozen case was a longish step to the rear, the Court later in the same term took a half pace forward. In Whelchel $v$. McDonald, ${ }^{30}$ a case in which the petitioner in substance contended that he had been denied due process by the military reviewing authorities' rejection of his claim of insanity, Mr. Justice Douglas duly recited the conventional propositions that the only issue was "jurisdiction" and that the military's errors in evaluating the evidence of insanity would not go to jurisdiction; but he added that the accused was entitled to an opportunity to present the defense of insanity and that a denial of that opportunity would have gone to jurisdiction. The petitioner had had that opportunity. There is nothing in the opinion to suggest that the result would have been different if the court-martial had found him mentally responsible after hearing a panel of seven psychiatrists unanimously testify that Whelchel was a hopeless lunatic; the error would have been only an error in evaluating the evidence. It has been said that Whelchel expanded the concept of "jurisdiction" in habeas corpus review of courts-martial, ${ }^{40}$ but the expansion is measurable with a micrometer.

\section{iII. Analogues in Civil Courts}

It is appropriate here to digress slightly to recall the history of the problem in its civilian form. It should not be forgotten that until shortly before World War II the scope of collateral review of civilian criminal proceedings was not appreciably greater; it too was said to go only to "jurisdiction" in the narrowest or "historic" sense.41 Historically, in fact, court-martial verdicts were more vulnerable to habeas corpus than were those of the civil courts: "at common law a judgment of conviction rendered by a court of general criminal jurisdiction was conclusive proof that confinement was legal," 42 while "a court martial was considered as one of those inferior courts of limited jurisdiction, whose judgment may be questioned collaterally," ${ }^{43}$ and from the earliest times a civil court could properly in-

37. 175 F.2d at 277.

38. Compare, e.g., Leyra v. Denno, 347 U.S. 556 (1954); Palmer v. Ashe, 342 U.S. 134 (1951); Gibbs v. Burke, 337 U.S. 773 (1949); Marino v. Ragen, 332 U.S. 561 (1947); Waley v. Johnston, 316 U.S. 101 (1942); Johnson v. Zerbst, 304 U.S. 458 (1938); United States ex rel. Goldsby v. Harpole, 249 F.2d 417 (5th Cir. 1957), cert. denied, 361 U.S. 850 (1959).

39. 340 U.S. 122 (1950), rehearing denied, 340 U.S. 923 (1951).

40. See Burns v. Lovett, 202 F.2d 335, 339 (D.C. Cir. 1952), rev'd sub nom. Burns v. Wilson, 346 U.S. 137, rehearing devied, 346 U.S. 844 (1953).

41. Matter of Gregory, 219 U.S. 210, 211 (1911); see separate opinion of Mr. Justice Frankfurter in Burns v. Wilson, 346 U.S. 844, 845-46 (1953). But cf. Frank v. Mangum, 237 U.S. 309 (1915).

42. United States v. Hayman, 342 U.S. 205, 210-11 (1952).

43. Ex parte Watkins, 28 U.S. (3 Pet.) 193, 209 (1830). 
spect at least the military' court's jurisdiction over the person and offense and the lawfulness of its sentence. ${ }^{44}$ Thus, President Lincoln's suspension of the writ of habeas corpus was intended and operated for the benefit of the various types of military tribunal which proliferated during the Civil War-indeed, the original suspension of April 27, 1861, took the form of an executive order delegating to the Commanding General of the United States Army and other military officers authority to suspend the writ. ${ }^{45}$ Not until 1867 did Congress cast the habeas corpus jurisdiction of the federal courts in substantially its present form by extending the writ to all cases in which "any person may be restrained of his or her liberty in violation of the constitution, or of any treaty or law of the United States." 48

It is noteworthy that neither tbat statute nor any amendment differentiates between civil and military tribunals. ${ }^{47} \mathrm{It}$ is true that Article 76 of the Uniform Code of Military Justice ${ }^{48}$ provides that

the proceedings, findings, and sentences of courts-martial as approved, reviewed, or affirmed as required by this code . . . shall be final and conclusive, and orders publishing the proceedings of courtsmartial and all action taken pursuant to such proceedings shall be binding upon all departments, courts, agencies, and officers of the United States, subject only to action upon a petition for a new trial as provided in article 73 and to action by the Secretary of a Department as provided in article 74, and the authority of the President.

But the Supreme Court refused to read the immediate predecessor of that article, whicb was worded no less categorically, as intended to deprive the civil courts of habeas corpus jurisdiction, ${ }^{49}$ and it is clear that Article 76 has no greater effect, as is demonstrated by the numerous cases subsequent

44. Wise v. Withers, 7 U.S. (3 Cranch) 330, 337 (1806); Ex parte Reed, 100 U.S. 13 (1879); see Ex parte Watkins, supra note 43, at 208-09.

45. See Ex parte Quirin, 317 U.S. 1, 31 n.10 (1942); Schaffter \& Mathews, The Powers of the President as Commander in Chief of the Army and Navy of The United States, H.R. Doc. No. 443, 84th Cong., 2d Sess. 4-5 (1956); cf. Ex parte Milligan, 71 U.S. (4 Wall.) 2 (1866); Ex parte Mudd, 17 Fed. Cas. 954 (No. 9899) (D.C.S.C. Fla. 1868). The report describes the Mudd case as "nowhere reported; opinion not now accessible," but summarizes it as holding that, "The crime of murdering the president of the United States, in time of civil war is triable by a military commission." Dr. Mudd was the luckless surgeon who set the broken leg of John Wilkes Booth and paid for this Samaritan act by many years of imprisonment in a peculiarly dismal jail.

46. Act of February 5, 1867, ch. 28, 14 Stat 385; see United States v. Hayman, 342 U.S. 205, 211-12 (1952); Hart \& Wechsler, The Federal Courts and the FEDERAL SYSTEM 1236-37 (1953).

47. The present statute provides in pertinent part that "the writ of habeas corpus shall not extend to a prisoner unless-(1) $\mathrm{He}$ is in custody under or by color of the authority of the United States or is committed for trial before some court thereof; or (3) $\mathrm{He}$ is in custody in violation of the Constitution or laws or treaties of the United States : . . ." 28 U.S.C. \$ 2241 (c) (1958).

48. 10 U.S.C. \& 876 (1958).

49. Gusik v. Schilder, 340 U.S. 128, 132 (1950); see Burus v. Wilson, 346 U.S. 137,142 (1953). 
to its enactment in which the Court has sanctioned the granting of the writ to persons convicted by court-martial. ${ }^{50}$

But, although historically the scope of collateral review of civilian criminal proceedings was not greater than that of courts-martial, a gradual development, inaugurated by the decision in Johnson $v$. Zerbst, ${ }^{51}$ has given new dimensions to the concept of examination in collateral proceedings of the "jurisdiction" of a civilian criminal court. The technical rationale is that jurisdiction, though it existed when the trial began, evaporated because the defendant was somehow denied constitutional due process. ${ }^{62}$ This latter is itself an uncertain but expanding concept which includes at least such basic unfairness as lack of counsel, ${ }^{53}$ or the admission of a coerced confession, ${ }^{54}$ or the prosecution's knowing use of perjured testimony ${ }^{65}$-all of which are as likely to occur in a court-martial as in a civilian criminal proceeding. Although even in civil cases old views die hard in some lower federal courts, ${ }^{56}$ it is clear today that if a district court is satisfied that a state prisoner was in fact denied the effective assistance of counsel or that a coerced confession was in fact admitted in evidence against him, it will grant the writ regardless of what the state court may have found on those issues. ${ }^{57}$ Whether it is desirable to employ this particular method of vindicating the state prisoner's federal constitutional rights is not the immediate question. ${ }^{58}$ For the present at least, that controversy has been

50. E.g., McElroy v. United States ex rel. Guagliardo, 361 U.S. 281 (1960); Grisham v. Hagan, 361 U.S. 278 (1960); Kinsella v. Singleton, 361 U.S. 234 (1960); Reid v. Covert, 354 U.S. 1 (1957); United States ex rel. Toth v. Quarles, 350 U.S. 11 (1955). These were all decided on the ground that a court-martial could not constitutionally exercise jurisdiction over sundry types of civilians and involved no question of loss of jurisdiction by unfairness amounting to a denial of due process.

At least one recent decision of a lower federal court included article 76 among its reasons for abstaining from collateral review of a military verdict. See Alley v. Chief, Finance Center, U.S. Army, 167 F. Supp. 303, 304 (S.D. Ind. 1958). The Government apparently takes the position that article 76 is at least a bar to a collateral attack by proceedings other than a petition for a writ of habeas corpus. See Begalke v. United States, No. 159-55, Ct. Cl., Jan. 20, 1960, cert. denied, 81 Sup. Ct. 108 (1960). Sec text accompanying notes $99-103$ infra.

51. 304 U.S. 458 (1938).

52. See Pollak, Proposals to Curtail Habeas Corpus for State Prisoncrs: Collatcral Attack on The Great Writ, 66 YALE L.J. 50, 52 (1956); Note, The Frecdom WritThe Expanding Use of Federal Habeas Corpuls, 61 HARv. L. REv. 657 (1948). (1938).

53. E.g., Wade v. Mayo, 334 U.S. 672 (1948); Johnson v. Zerbst, 304 U.S. 458

54. Leyra v. Denno, 347 U.S. 556 (1954).

55. Ex parte Hawk, 321 U.S. 114 (1944).

56. Cf. Wooten v. Bomar, 267 F.2d 900 (6th Cir. 1959). See also Reitz, Fedcral Habeas Corpus: Postconviction Remedy for State Prisoners, 108 U. PA. L. Rev. 461, $462(1960)$.

57. See Brown v. Allen, 344 U.S. 443 (1953) ; House v. Mayo, 324 U.S. 42 (1945).

58. The problem of the proper extent of federal intervention in this area-whether for example, it ought to be limited to the Supreme Court's review, usually on certiorari, of the judgments of state courts, and whether the Supreme Court ougbt to think quite so expansively when defining due process-has naturally provoked an exceedingly hot controversy and a correspondingly voluminous literature, judicial and otherwise, most of it highly polemical. See, e.g., Report of the Committec on Habcas Corpus of the Conference of Chief Justices (1954), reprinted in H.R. REP. No. 1293, 85th Cong., 
resolved in favor of the proposition that the federal courts may examine for themselves the fairness of a petitioner's trial in a state court and may range far beyond the record in the course of that examination. The not less important question with which we are here concerned and which the Supreme Court will sooner or later have to decide, is whether there is any good reason why military tribunals should not be subject to the same quality of constitutional policing as is applied to the criminal proceedings of the courts of the states-emphasizing, however, that procedures which would invalidate a civilian trial may be justified by military exigency. The process which is due a soldier is not necessarily the same as that due a civilian.

\section{Burns v. Wilson: The Supreme Court's Most Recent View}

Three years after Whelchel $v$. McDonald the Supreme Court decided Burns v. Wilson, ${ }^{59}$ which after seven years still stands as the principal lighthouse in these trackless waters, however low its candlepower. On its facts it presented precisely the question posed in the preceding paragraphwhether and to what extent the principle of Johnson $v$. Zerbst ought to be applied to collateral review of court-martial verdicts. Burns and another soldier had been convicted by general court-martial of rape and murder and sentenced to death. Having exhausted the procedures of military review, they petitioned for writs of habeas corpus in the District Court for the District of Columbia. ${ }^{60}$ Burns and his copetitioner made a number of

2d Sess. 7 (1958) ; concurring opinion of Mr. Justice Jackson in Brown v. Allen, 344 U.S. 443, 532 (1953) ; Pollak, supra note 52; Reitz, supra note 56.

59. 346 U.S. 137, rehearing denied, 346 U.S. 844 (1953).

60. Burns and his copetitioner had a troublesome preliminary problem, for they were confined in Japan and thus several thousand miles beyond the territorial jurisdiction of any district court of the United States. The statute, 28 U.S.C. § 2241 (a) (1958), which permits federal courts to grant the writ "within their respective jurisdictions," has been construed by the Supreme Court to require a petitioner to file in the court for the district in which he is confined. Ahrens v. Clark, 335 U.S. 188 (1948); see Whiting v. Chew, 273 F.2d 885, 886 (4th Cir. 1960). But the opinion in Ahrens v. Clark, sipra, explicitly left open "the question of what process, if any, a person confined in an area not subject to the jurisdiction of any district court may employ to assert federal rights," id. at 192 n.4; see Comment, 49 MrCH. L. REv. 870 (1951), and the Supreme Court has yet to dispose of that question. The Court of Appeals for the District of Columbia Circuit, which held in Eisentrager v. Forrestal, 174 F.2d 961 (D.C. Cir.), rev'd on other grounds sub nom. Johnson v. Eisentrager, 339 U.S. 763 (1949), that one confined in Germany could petition in the district where his custodian, or a person having authority over that custodian, such as the Secretary of Defense, was located, has stuck to that position, at least in cases in which the petitioner was an American citizen. Day v. Wilson, 247 F.2d 60 (D.C. Cir. 1957); Cozart v. Wilson, 236 F.2d 732 (D.C. Cir.), vacated as moot, 352 U.S. 884 (1956).

The Government's policy on the matter is very far from clear. In U.S. ex rel. Toth v. Quarles, 350 U.S. 11 (1955), in which the petitioner had been apprehended in Pittsburgh and promptly flown to Korea to be court-martialed, the Government conceded the district court's jurisdiction to entertain the petition, but did so on the tortuous reasoning that since Toth might have sought the writ at any time after his apprehension and before his removal from the United States, he was to be distinguished from "a person [who] has never had a cause of action which was clearly within the jurisdiction of a district court of the United States, as, for example, an Ameriean citizen apprehended outside the territorial or maritime jurisdiction of the United States 
allegations, supported by possibly truthful affidavits and other evidence outside the record, which raised in the mind of one circuit judge such "serious doubt whether 'the whole course of events' from apprehension to conviction did not amount to a serious denial of fundamental fairness" that he wanted the case remanded for a hearing on the merits. ${ }^{01}$ The petitioners alleged that they had been illegally detained; that their confessions had been coerced; that they had been denied the effective assistance of counsel; that favorable evidence had been suppressed and perjured testimony knowingly used; and that the trial was conducted in an atmosphere of "hysteria and terror." ${ }^{2}$ The district court summarily dismissed the petitions on the traditional grounds. The court of appeals, though it examined the record in detail, affirmed-essentially on the ground that these issues of fact had been presented to and fully explored and resolved by the military authorities upon "substantial evidence."

In the Supreme Court four different opinions were filed; none was supported by a majority of the Court. In what many lower courts seem to have mistaken for a majority opinion, the largest faction, consisting of Mr. Chief Justice Vinson and Justices Clark, Burton and Reed, voted to affirm, stating that:

1. "The constitutional guarantee of due process is meaningful enough, and sufficiently adaptable, to protect soldiers-as well as civilians-from the crude injustices of a trial so conducted that it becomes bent on fixing guilt by dispensing with rudimentary fairness . . . .003

2. "But in military habeas corpus the inquiry, the scope of matters open for review, has always been more narrow than in civil cases."04 If the

by authority of the United States," Brief for the Respondent, p. 53 n.29, U.S. ex rel. Toth v. Quarles, supra; see 350 U.S. at 25 (Reed, J., dissenting). Since Toth was arrested in Pittsburgh on May 13, flown to Maryland on the same day, to California on May 15, and to Korea on the day after, he would have had to display both presence of mind and rapid legal footwork to file a petition in a district in which he was confined. In a subsequent case in which the petitioning soldier had been apprehended, and was at the time he filed, confined outside the jurisdiction of the United States, the Government argued, though unsuccessfully, that the district court was without jurisdiction. Day v. Wilson, 247 F.2d 60 (D.C. Cir. 1957). Since on remand the petition was found to be without merit, no review of the question of territorial jurisdiction could be sought. Day v. Wilson, 155 F. Supp. 469 (D.D.C. 1957). The most that can be said is that the Government stops short of the position that it can frustrate the writ by the simple expedient of spiriting a prisoner out of the country. The problem, however intriguing, is probably not of major practical importance in time of peace, because soldiers who are sentenced to death or terms of imprisonment sufficiently long to afford time for the filing and hearing of a petition will normally be returned to the United States for execution or confinement. In the Burns case a majority of the Court, and apparently the parties as well, simply ignored the question, though Mr. Justice Frankfurter vigorously advocated its confrontation and decision. 346 U.S. at 851-52 (dissenting opinion).

61. See Burns v. Lovett, 202 F.2d 335, 348, 352-53 (D.C. Cir. 1952) (Bazelon, J., dissenting), aff'd sub nom. Burns v. Wilson, 346 U.S. 137 (1953).

62. See Burns v. Lovett, supra note 61 , at 343-46.

63. 346 U.S. at 142.

64. Id. at 139 . 
Uniform Code's provision that the determination of military tribunals shall be final and binding on all courts does not altogether preclude habeas corpus jurisdiction, yet "these provisions do mean that when a military decision has dealt fully and fairly with an allegation raised in that application, it is not open to a federal civil court to grant the writ simply to re-evaluate the evidence." $"$ 65

3. Thus, in the instant case, "had the military courts manifestly refused to consider" the petitioners' allegations of fundamental unfairness, the district court might have evaluated for itself the question of due process. But, since the record showed that the military courts "have heard petitioners out" on these matters, nothing remained for the civil courts to do. ${ }^{66}$

Justices Jackson and Minton concurred in the result. ${ }^{87}$ The former wrote no opinion, and the latter registered his pronounced and explicit disapproval of the idea that "the federal courts sit to protect the constitutional rights of military defendants," beyond satisfying themselves of the existence of jurisdiction in the traditional sense; he attested his orthodoxy by citing In re Grimley. ${ }^{68} \mathrm{Mr}$. Justice Frankfurter cast a vote in favor of more light; he was unwilling either to affirm or reverse without more and fuller argument of the "questions of great delicacy and difficuty" that the case presented. ${ }^{69}$ Nevertheless, he did not wait for a fuller canvass of the problem to make the essentials of his position pretty clear:

I cannot agree that the only inquiry that is open on an application for habeas corpus challenging a sentence of a military tribunal is whether that tribunal was legally constituted and had jurisdiction, technically speaking, over the person and the crime. Again, I cannot agree that the scope of inquiry is the same as that open to us on review of State convictions; the content of due process in civil trials does not control what is due process in military trials. Nor is the duty of the civil courts upon habeas corpus met simply when it is found that the military sentence has been reviewed by the military hierarchy, although in a debatable situation we should no doubt attach more weight to the conclusions reached on controversial facts by military appellate courts than to those reached by the highest court of a state. ${ }^{70}$

On petition for rehearing he added a significant gloss to his first opinion; demanding "well-focused argument and careful deliberation before

65. Id. at 142 .

66. Id. at $142-44$.

67. Id. at 146 .

68. Id. at $146-47$.

69. Id. at 148-49. As in the cases involving court-martial jurisdiction over civilians, the size of the problem was much magnified in Mr. Justice Frankfurter's mind by the fact that life was at stake. Compare Reid v. Covert, 354 U.S. 1, 41 (1956) (concurring opinion); Kinsella v. United States ex rel. Singleton, 361 U.S. 234, 249 (1960) (Harlan, J. dissenting with Frankfurter, J., concurring).

70. 346 U.S. at 149. 
enunciating the principle that a conviction by a constitutional court which lacked due process is open to attack by habeas corpus while an identically defective conviction when rendered by an ad hoc military trubunal is invulnerable," 71 he made it clear that he saw no reason for treating the principle of Johnson $v$. Zerbst-the principle that jurisdiction may be "lost" by a denial of whatever process is due in the circumstances-as any less applicable to military than to civil courts.

Justices Black and Douglas, though what they had to say seems not at bottom very different from the Frankfurter dicta, flatly dissented. ${ }^{72}$ They saw no need for reargument to persuade them that some, if not all, of the rights conferred by the fifth and sixth amendments applied to soldiers $;^{73}$ if not, they asked, why did the draftsmen of the fifth amendment think it necessary explicitly to except cases arising in the land or naval forces from the requirement of a presentment or indictment of a grand jury? The Court, they went on to say, had in fact already held in Wade v. Hinter ${ }^{74}$ that the double jeopardy provision of that amendment was applicable to military proceedings; and surely the right not to be compelled to be a witness against oneself is not less fundamental. Therefore, it was not enough that the military authorities might have given fair consideration to the constitutional question; the petitioners were entitled to a judicial hearing on the circumstances surrounding their confessions, and to have those circumstances tested by the standards of due process formulated by the Supreme Court-not merely by whatever standards might have been formulated by Congress in the Uniform Code of Military Justice.

Unfortunately, the reasoning of the dissent lent little or no force to its conclusion, however right that conclusion may be. In the first place, the textual argument is very infirm, if only because it proves a great deal too much. By a parity of reasoning it could be shown that the framers of the Bill of Rights intended to apply to courts-martial the sixth amendment's requirement for "all criminal prosecutions" of an "impartial [petty] jury of the State and District wherein the crime shall have been committed" -an obviously impossible construction, not favored by either Mr. Justice Black or Mr. Justice Douglas. ${ }^{75}$ Moreover, the exclusio uninus rule of con-

71. 346 U.S. 851.

72. 346 U.S. at 150.

73. Justices Black and Douglas were no strangers to this concept of an adjustable Bill of Rights, for they had earlier suggested in the course of their dissent in Johnson v. Eisentrager, 339 U.S. 763, 791 (1949), that some, but not all, parts of the Bill of Rights applied to the actions of American Military Government in occupied foreign territory. Cf. Best v. United States, 184 F 2d 131, 138 (1st Cir. 1950), ccrt. dcnicd, 340 U.S. 939, rehearing denied, 341 U.S. 907 (1951).

74. 336 U.S. 684 (1949).

75. See Reid v. Covert, 354 U.S. 1, 37 n.68 (1957) ; Duke \& Vogel, The Constitutiont and the Standing Army: Another Problem of Court-Martial Jurisdiction, 13 VaNd. L. REv. 435, 441 (1960). 
struction is, after all, no more than an aid in deciphering the intention of those responsible for the amendments; and, since the Burns case was decided, Colonel Wiener has convincingly demonstrated that the fathers of the Bill of Rights never supposed that any part of it applied to soldierswhich, of course, as Colonel Wiener emphasized, does not mean that no part of it should today be held to apply to military trials. ${ }^{76}$ Secondly, Wade v. Hunter simply is not authority for the proposition for which the dissenters cited it, for what it actually held was no more than that "under the circumstances shown, the Fifth Amendment's double jeopardy provision did not bar petitioner's trial before the second court-martial," because that second trial "was not the kind of double jeopardy within the intent of the Fifth Amendment." 77 Four years later, indeed, in Reid v. Covert, ${ }^{78} \mathrm{Mr}$. Justice Black, in an opinion in which Mr. Justice Douglas concurred, buttressed his conclusion that courts-martial could not constitutionally be used for the trial of civilians by animadverting on the inadequate constitutional protection afforded the accused in such proceedings. By way of illustration he pointed out that "in Swain v. United States . . . this Court held that the President or commanding officer had power to return a case to a court-martial for an increase in sentence. If the double jeopardy provisions of the Fifth Amendment were applicable such a practice would be unconstitutional."79 Since Wade v. Hunter was not so much as mentioned, it may be inferred that the dissenters in Burns had had second thoughts about the meaning of that case.

\section{The Constrtutional Question}

The question of the applicability of the Bill of Rights to military trials, which, of course, lies at the root of the question of the scope of

76. See Wiener, Courts-Martial and the Bill of Rights: The Original Practice, 72 Harv. I. Rev. 266, 298-302 (1958). But see Henderson, Courts-Martial and the Contstitution: The Original Understanding, 71 HARV. L. REv. 293 (1957).

77. 336 U.S. at $688-89,690$. The Court reasoned that, just as the double jeopardy provision leaves to a civil judge broad discretion to terminate a trial before final judgment, whenever he thinks that justice requires such a termination, so the military authorities must be given some leeway in deciding when the circumstances-including the military tactical situation-justify starting a court-martial all over again, perhaps before a different court. In the Wade case, a court-martial of the 76th division recessed to permit the calling of additional witnesses; by the time the witnesses were obtained, the 76th division, including all the personnel of the court, had advanced far to the east of the scene of the crime and the residence of the witnesses. Accordingly, the charges were referred to Fifteenth Army, whose headquarters had moved into that vicinity. The opinion of the Court, written by Mr. Justice Black, does seem to assume the applicability of the double jeopardy provision; but a footnote states that, "Our holding that under the circumstances here the Fifth Amendment did not bar trial by the second court-martial makes it unnecessary to consider ... to what extent a courtmartial's overruling of a plea of former jeopardy is subject to collateral attack in habeas corpus proceedings." Id. at 688 n.4. The dissenting Justices, including Mr. Justice Douglas, thought that the effect of the Court's decision was to deprive Wade "of his right under the Constitution to be free from being twice subjected to trial for the same offense." Id. at 694.

78. 354 U.S. 1 (1957).

79. Id. at 37 n.68. 
review of such trials by the civil courts, is thus left in considerable doubt. It seems safe to assume that the dictum of Mr. Chief Justice Chase that "the power of Congress in the government of the land and naval forces and of the militia, is not at all affected by the fifth or any other amendment,"80 is not the law today, if it ever was ${ }^{81}$ it is now reasonably certain that soldiers have some constitutional rights, that they are entitled to some minimum of due process which the courts will defend against encroachment by either Congress or the military authorities. What is not so clear is whether the quantum of due process to which the Constitution entitles them is large enough to have much practical significance.

Argument about the applicability of the Bill of Rights to courts-martial looks, from one standpoint, largely academic, because only a few of the explicit guarantees of the Bill of Rights, other than those relating to grand and petty juries, have not been granted to members of the armed forces by Congress. ${ }^{82}$ The basic, explicit protections are all present and accounted for: thus, the Uniform Code prohibits compulsory self-incrimination, double jeopardy, and cruel or unusual punishments ;3 the accused must be apprised of the charges against him; he is to be assisted by counsel of his choice and to have the benefit of compulsory process. ${ }^{84}$ It is the duty of the military reviewing authorities, the Boards of Review and the Court of Military Appeals, to see to it that these and other aspects of "military due process," such as the outlawing of attempts by commanding officers to influence the action of a court-martial, ${ }^{86}$ are strictly observed. Normally, of course, they

80. See Ex parte Milligan, 71 U.S. (4 Wall.) 2, 138 (1867) (concurring opinion).

81. "As yet it has not been clearly settled to what extent the Bill of Rights and other protective parts of the Constitution apply to military trials." Reid v. Covert, 354 U.S. 1, 37 (1957). But see Easley v. Hunter, 209 F.2d 483, 486 (10th Cir. 1953).

82. The principal exceptions are the right to be admitted to bail and the right to confrontation. Bail has never been known to the military law. See United States ex rel. Watkins v. Vissering, Misc. No. 722, E.D. Va., June 10, 1960; Wintrrop, Military Law and Precenents 114 (2d ed. 1920). Article 49(d) of the Úniform Code permits the use of depositions in non-capital cases but has recently been construed to require, even in such cases, that the accused and his counsel be present at the taking of the deposition, on the ground that a literal construction would "lend itself" to conflict with the sixth amendment requirement of confrontation. United States v. Jacoby, 11 U.S.C.M.A. 428, 29 C.M.R. 244 (1960).

83. 10 U.S.C. $\$ \S 831,844,855$ (1958). There may be some significance in the fact that, whereas the eighth amendment prohibits "cruel and unusual punishments," the Uniform Code bars "cruel or unusual punishment" [emphasis added]. Until the Civil War, some military punishments, such as flogging and branding, were cruel but far from unusual; others, such as shaving the head or causing the offender to wear a barrel, were more unusual than cruel. See Wrnthrop, Mrlitary Law and Precedents 437-42 (2d ed. 1920).

84. 10 U.S.C. $\S 8830(b), 838,846$.

85. United States v. Clay, 1 UU.S.C.M.A. 74, 1 C.M.R. 74 (1951).

86. 10 U.S.C. \& 837 (1958). The Court of Military Appeals recently reversed a conviction on a charge of uttering forged checks because, inter alia, it thought that this article had been violated by the commanding officer's promulgation, some time before, of a bull on "Dishonored Checks," deploring their incidence in the command and exhorting recomputation of the bank balance immediately after the writing of a check. United States v. Olson, 11 U.S.C.M.A. 286, 29 C.M.R. 102 (1960). 
do so, sometimes with a zeal which strikes some observers as verging on the excessive. ${ }^{87}$

But, from another standpoint, the provenance of the soldier's rights, and the identity of the tribunal that enforces them, may have genuine importance. As competent and conscientious as the military, reviewing authorities created by Congress may be in normal times, it is precisely in abnormal times that military justice is put to its severest tests and that those responsible for its administration are least likely to be skilled in military law and most likely to be tempted to subordinate fairness to seeming expediency. The history of Ameriean military justice has for this reason followed a cyclic pattern, like most other aspects of American military policy. After every war there are loud and sometimes justified squawks about the unnecessary roughness of martial courts and cops, followed by a tremendous

87. The delicate perceptions of the present Court of Military Appeals, or at least of two of its three members, have sniffed out fatal denials of due process in situations in which their presence would probably not have been noticed by most civilian judges. Thus, to select a couple of recent examples, the failure of one defense counsel to proffer certain evidence that the majority of the Court of Military Appeals thought would have been mitigating, and the decision of another not to make a particular defense that he thought devoid of merit-in cach case in circumstances in which the dissenting judge thought reasonable lawyers might differ as to the preferable trial tactics for the defense-were found by the majority of the court to evidence such negligence, incompetence, or indifference to the client's welfare as to amount to a denial of the assistance of counsel. United States v. Huff, 11 U.S.C.M.A. 397, 29 C.M.R. 213 (1960); United States v. Horne, 9 U.S.C.M.A. 601, 26 C.M.R. 381 (1958). An equally interesting example of tender solicitude for the accused's rights is United States v. Allen, 11 U.S.C.M.A. 539, 29 C.M.R. 355 (1960), in which the same majority of the court reversed on the ground, inter alia, that the substantial rights of the accused were prejudiced by a prosecutor's reference in his closing peroration to a scene in a bestselling novel, "Anatomy of a Murder," in which a defense lawyer artfully stimulates his client to "remember" episodes supporting his defense of insanity. By ordinary civilian standards of permissible prosecution rhetoric, this literary allusion seems comparatively mild. Thus, in a mail fraud case in which the prosecuting attorney had denounced a defendant as an "adept prevaricator," "the most successful faker in the history of fakery," a "cheat," a "charlatan," and a "religious racketeer," a majority of the Court of Appeals opined that "if the conduct of the prosecution in argument in this case constitutes error, then the prosecution in every case is limited to a listless, vigorless summation of fact in Chesterfieldian politeness. Gone are the days of the great advocates whose logic glowed and flowed with the hcat of forensics!" Ballard v. United States, 152 F.2d 941, 943 (9th Cir. 1945), rev'd on other grounds, 329 U.S. 187 (1946); cf. Di Carlo v. United States, 6 F.2d 364 (2d Cir. 1925). Were the sensitivity displayed by the present Court of Military Appeals applied by civilian courts of appeal to the conduct of the ordinary criminal trial in an inferior state court, we should probably witness something approximating a general jail delivery. Nor has the Court of Military Appeals hesitated to strike down provisions of the Mamual for Courts-Martial, which embodies the President's regulations implementing the Uniform Code, as violative of military due process. United States v. Haynes, 9 U.S.C.M.A. 792, 27 C.M.R. 60 (1958); see Fratcher, Presidential Power to Regulate Military Justice: A Critical Study of Decisions of the Court of Military Appeals, 34 N.Y.U.L. Rev. 861, 878-82 (1959). On the other hand, under article $67(d)$ of the Uniform Code, the Court of Military Appcals "shall take action only with respect to matters of law," which means that the military Board of Review is the last appellate body having authority to determine such questions of fact as the voluntariness of a confession. United States v. Stivers, 11 U.S.C.M.A. 512, 29 C.M.R. 328 (1960). But since the Court of Military Appeals may (and often does) find that a confession was involuntary as a matter of law, and since the line between questions of fact and questions of law is no better defined in military than civil law, this limitation on its power of review may not have much practical significance. 
pother in Congress, followed by a grand general renovation of the Articles of War, followed by profound public apathy until the next emergency. ${ }^{88}$ After each World War Congress stuffed the military code with humane provisions intended to protect poor privates from high-handed injustice at the hands of drumhead courts-martial composed of arrogant martinetssome of them so protective as possibly to be unworkable in wartime conditions $s^{89}$ and therefore likely at best to be unenthusiastically obeyed and at worst to be systematically evaded. Experience suggests that a better guarantee of fundamental fairness in military trials is the existence of some degree of power, altogether outside the statutory system of military justice, to enforce such fairness.

In short, in time of actual military emergency it may make a great deal of difference whether the civilian courts or the military authorities are to have the ultimate right to decide if a soldier accused of crime has in fact received whatever process is due him. At least to the extent that those rights stem not merely from a Congressional act of grace-wbich, it must be remembered, can at any time be rescinded ${ }^{09}$ - but from the Constitution itself, it is hard to see why the federal civil courts should be any more backward in enforcing their observance in military trials than they are in enforcing constitutional rights in state trials. Congress may have made the Court of Military Appeals the final arbiter of the meaning of the Uniform Code of Military Justice, but the Supreme Court of the United States is the final arbiter of the meaning of the Constitution of the United States. ${ }^{91}$

Viewed from this standpoint, the plurality opinion in Burns v. Wilson seems to contain serious internal contradictions. It is all very well to say that constitutional due process protects soldiers from "crude injustice," but what if the crude injustice takes the form of a finding, in the teeth of the evidence, that a coerced confession was voluntary and admissible? There

88. Who now remembers the First World War's Hard-Boiled Smith and his Paris guardhouse, or even the Second's Colonel Kilian and his Lichfield guardhouse? Yet the one contributed greatly, however unintentionally, to the 1920 revision of the Articles of War, and the other did the same for the Uniform Code.

89. See The United States Court of Military Appeals and the Judge Advocates General of the Armed Forces and the General Counsel of the Departanent of the Treasury, AnNual Report 21, 29, 51 (1954).

90. See Reid v. Covert, 354 U.S. 1, 37 (1957).

91. Here, at the risk of sounding like Gertrude Stein, it ought to be rciterated that the process which is due a soldier may be less than, or at least different from, that which is due a civilian. Due process is not "the same in a military setting as it is in a civil setting." Burns v. Lovett, 202 F.2d 335, 352 (D.C. Cir. 1952) (Bazelon J., dissenting), aff'd sub nom. Burns v. Wilson, 346 U.S. 137 (1953), quoted with approval by Mr. Justice Frankfurter in Burns v. Wilson, supra at 149. For example, if in a civil case an accused were confined in an unheated jail and inadequately fed, a confession made in such circumstances might well be regarded as coerced; but a court might take a different view in a military situation in which no more comfortable quarters were to be had and the guards got no better rations than the prisoner. So in Wade v. Hunter, 336 U.S. 684 (1949), assuming the applicability of the double jeopardy clause of the fifth amendment, the exigencies of the military situation were held to justify a second trial which might well have been held unconstitutional in a civilian context. 
may be no more injustice in a naked refusal to listen than there is in a patient, if bored, hearing of the accused's allegations, followed by an arbitrary finding either that they are untrue or that they do not amount to a denial of due process. Yet Mr. Chief Justice Vinson's opinion may be interpreted as meaning that anything short of "manifest refusal to consider" allegations that due process has been denied is equivalent to dealing with them "fully and fairly" and that the Constitution protects a soldier against nothing more than "a trial so conducted that it becomes bent on fixing guilt by dispensing with rudimentary fairness." Such language might impose a siguificant limitation on, say, Dr. Castro's notions of a proper military trial, but very few modern American trials, military or civilian, no matter how unfair by our standards, could measure down to such a test.

There seems thus to be nothing in Burns v. Wilson, even if the Chief Justice's opinion had been an opinion of the Court, which in practice would require a district court to apply to collateral review of a court-martial conviction any test more exacting than the traditional one of jurisdiction over the person and offense and power to impose the sentence. But if there are few, if any, records showing that the military authorities literally "refused to consider" allegations of unfairness, there are some that may raise a substantial question whether the consideration was "full and fair." Treating the principal opinion in the Burns ease as the controlling precedent, a court may simply and summarily dismiss a petition on the ground that the military did not refuse to consider its allegations or it may, with equal ease and upon the same authority, stress the requirement that military consideration shall have been full and fair.

No appreciable clarification is to be found in the two subsequent decisions of the Supreme Court considering soldiers' petitions for habeas corpus. In those cases $^{03}$ the petitioners had been convicted of murder and attempted rape and sentenced to life imprisonment, the minimum sentence for murder. Since court-martial procedure requires a single gross sentence, ${ }^{94}$ regardless of the number of charges of which the accused may have been convicted, there was no separate sentence for the attempted rape, and no way of telling what sentence the court-martial would have imposed for that crime

92. This appears to be the interpretation placed on the opinion by the Department of the Army and the Department of Justice. See Brief for the Respondent, p. 6, Burns v. Looney, No. 2699 H.C., D. Kan., April 13, 1959, aff'd sub nom. Burns v. Taylor, 274 F.2d 141 (10th Cir. 1959), in which it is uncompromisingly asserted that "the law [is] that civil courts, on habeas corpus, will consider claims of military prisoners that they were denied constitutional rights only if the military tribunals manifestly refuse to consider such claims."

93. Jackson v. Taylor, 353 U.S. 569 (1957) ; Fowler v. Wilkinson, 353 U.S. 583 (1957).

94. Manual for Courts-Martial United States app. 8a, at 521 (1951); see Edwards v. Madigan, 281 F.2d 73, 75-76 (9th Cir. 1960); Note; Habeas Corpus Review of Military "Gross Sentence" Usage, 65 Yale L.J. 413 (1956). 
alone. The Board of Review, affirming only the conviction for attempted rape, imposed a 20 year sentence, which was the maximum allowable for that crime. There were no allegations that the conviction was tainted by any unfairness, and the sole question was whether the Uniform Code empowered the Board so to impose what the petitioner argued to be a new sentence rather than a modification of a court-martial sentence-a question well within the civil court's traditional jurisdiction to pass upon the power to impose a sentence.95 A majority of the Court held the sentence authorized by the Code and refused to consider its harshness, complained of by one petitioner, on the unexceptionable ground that such matters are wholly within the discretion of the military. They saw no constitutional question, and they put no gloss on Burns v. Wilson. ${ }^{96}$

\section{Collateral Review in the Lower Courts Since Burns v. Wilson}

The rich variety of opinions expressed by the Supreme Court may help to account for the fact that the reported opinions of the lower federal courts since Burns v. Wilson, although numerous, do not lend themselves to facile taxonomy. They have, indeed, one striking common feature; in not one of them did a soldier-petitioner succeed in obtaining his liberty. 97 Perhaps it is possible to make another significant generalization: the courts, whatever disclaimers they may voice, do in fact usually examine the record with care to see if there is support for allegations of unfairness. Thus, it may be suggested that the monotony of result is attributable not so much to judicial abnegation of power to review the fairness of military proceedings as to the simple fact that, in the more or less peaceful conditions which have prevailed since the Korean armistice, such proceedings, original and ap-

95. See Fischer v. Ruffner, 277 F.2d 756, 758 (5th Cir. 1960).

96. The four dissenting Justices, Mr. Chief Justice Warren and Justices Black, Douglas and Brennan, thought that the court-martial had not dealt "fully and fairly" with the petitioners, because its Law Officer gave the members of the court no instructions concerning the punishment that could be imposed for attempted rape-which suggests that these Justices thought the correctness of a court-martial's instruction on the law to be within the proper scope of collateral review. See text accompanying notes 109,129 infra.

97. This statement requires a minor caveat, for two limited successes were scored. One petitioner induced a civil court to swallow the exceedingly dubious proposition that provision in the Articles of War for "imprisonment for life" gave a court-martial no authority to direct confinement at hard labor. McKinney v. Finletter, 205 F.2d 760 (10th Cir. 1953). A subsequent attempt by the same petitioner to recover his liberty as well as his leisure failed. McKinney v. Warden, 273 F.2d 643 (10th Cir. 1959), cert. denied, 363 U.S. $816(1960)$. In another case, the court, although it found no defects in the petitioner's conviction, held that changing the place of confinement from a federal reformatory to a federal penitentiary amounted to an increase in the sentence, in contravention of the Uniform Code, and that the petitioner was entitled to be transferred to an institution of the former type. Sweet v. Taylor, 178 F. Supp. 456 (D. Kan. 1959) ; cf. Kelly v. Hunter, 80 F. Supp. 851 (D. Kan. 1948) aff'd sub nom. Yates v. Hunter, 174 F.2d 347 (10th Cir. 1949). These, of course, were essentially questions of the military authorities' power to impose particular sentences and so by any test were fair subjects for collateral review. 
pellate, have typically been at least as fair as the Bill of Rights, assuming its applicability, would require them to be. None of the opinions leaves the reader with any, conviction that the outcome would have been different if a civilian trial had been involved and the doctrine of Johnson v. Zerbst applied to its fullest extent. Nevertheless, the application by the lower federal courts of the principles, such as they are, laid down by the Supreme Court deserves attention. Should military justice again be faced with the unpeaceful conditions that produced the last crop of hard cases, these are the precedents that the civil courts will presumably have to follow, distinguish, or overrule when they are called on to undertake collateral review of military sentences.

Habeas corpus, though by far the commonest, is not the only method of collateral review. There are a sizeable group of cases in which the military convict seeks some relief other than the preservation of his life or the restoration of his liberty. He may, for example, bring a suit for back pay in the Court of Claims on the theory that a court-martial sentence expelling him from the service was a nullity. The celebrated Shapiro case, decided shortly after World War II, was a spectacularly successful example of such a suit. In that case the Courts of Claims, finding gross violations of the plaintiff's rights under the fifth and sixth amendments, notably denial of the effective assistance of counsel, concluded that his court-martial conviction was void and the sentence of dismissal consequently illegal.88 It has been suggested that the subsequent enactment of article 76 of the Uniform Code, 99 purporting to make court-martial sentences binding on all courts of the United States, may have deprived at least the Court of Claims, a legislative court, of jurisdiction collaterally to review courts-martial.100 Moreover, Burns v. Wilson may be thought to limit the force as precedent of the Shapiro case-although it is a somewhat odd fact that neither the principal opinion, the dissent, nor any of the briefs in Burns v. Wilson so much as mentioned Shapiro. ${ }^{101}$ Despite these considerations, the Court of Claims itself showed no inclination to retreat from the view that a substantial denial of constitutional rights operated as effectively to divest a court-martial of jurisdiction as a civil court, ${ }^{102}$ until very recently when Mr. Justice Reed, sitting as a judge of the Court of

98. Shapiro v. United States, 69 F. Supp. 205 (Ct. C1. 1947); see note 26 supra; cf. United States v. Brown, 206 U.S. 240 (1907).

99. 10 U.S.C. \$ 876 (1958). Article 76 was preceded, in 1948, by an amendment of the Articles of War, of similar purport. 64 Stat. 635 (1948).

100. See Wiener, The Neze Articles of War, Infantry J., Sept. 1948, p. 24, at p. 29; Pasley, supra note 4 , at 34 .

101. See separate opinion of Mr. Justice Frankfurter in Burns v. Wilson, 346 U.S. $844,847-48$ (1953).

102. See Griffiths v. United States, 172 F. Supp. 691, 693 (Ct. Cl.), cert. denied, 361 U.S. 865 (1959). 
Claims, obliquely suggested that, should a case be presented in which a court-martial had not given "fair consideration to petitioner's constitutional rights," article 76 might require that court to reconsider the question of its jurisdiction to entertain a collateral attack on a final judgment of a court-martial. ${ }^{103}$

For those whose grievances can be assuaged neither by the great writ nor by an action for back pay, there remains the possibility of an action for a judgment declaratory of the invalidity of a court-martial sentence ${ }^{104}$ or even an action for wrongful imprisonment. ${ }^{105}$

But petitions for habeas corpus have naturally furnished most of the occasions for the lower courts to peer into the somewhat clouded crystal ball of Hiatt v. Brozen and Burns v. Wilson, and it is principally the decisions in those cases that will help or hinder collateral review of military justice in any future emergency. The interesting question, of course, is the extent to which lower federal courts have continued to treat courts-martial as a class apart and their verdicts as peculiarly privileged.

At the outset, failure to assert a claim of unfairness in the original proceeding, including its appellate phases, is likely to be a worse stumbling block for the military than for the civilian petitioner, if only because it is hard to say that the military authorities "refused to consider," or did not fully and fairly consider, a point that was never urged upon them. A num-

103. Begalke v. United States, No. 159-55, Ct. Cl., Jan. 20, 1960, cert. devied, 81 Sup. Ct. 108 (1960).

104. Jackson v. McElroy, 163 F. Supp. 257 (D.D.C. 1958). The plaintiff, an officer, had been sentenced to a substantial forfeiture of pay and "to lose 250 unrestricted numbers." The exact nature of the latter esoteric punishment, which is found only in the Navy and Marine Corps, see MANUAL For Courts-Martiat. United States II 126 (1951), is not wholly clear to me, but it obviously dealt a heavy blow to plaintiff's chances of promotion and could hardly be corrected by either habeas corpus or a suit in the Court of Claims. The district court, although it found no merit in the contention that the convening authority was an "accuser" within the meaning of articles 1(11) and $22(\mathrm{~b})$ of the Uniform Code, and that the court-martial had therefore had no jurisdiction, assumed that an action for a declaratory judgment was a proper way of attacking the court-martial's jurisdiction. Contra, Brown v. Royall, 81 F. Supp. 767 (D.D.C. 1949), cert. denied, 339 U.S. 952 (1950). Compare Harmon v. Brucker, 355 U.S. 579 (1958); Ives v. Franke, 271 F.2d 469 (D.C. Cir.), cert. denied, 361 U.S. 965 (1959). The District Court for the District of Columbia has jurisdiction to issue a writ of mandamus to the appropriate official. Cf. Olenick v. Brucker, 173 F. Supp. 493 (D.D.C.), order set aside and case remanded, 273 F.2d 819 (D.C. Cir. 1959); 69 YALE L.J. 474 (1960).

105. McLean v. United States, 73 F. Supp. 775 (W.D.S.C. 1947); cf. Dynes v. Hoover, 61 U.S. (20 How.) 65 (1858) ; Zimmerman v. Poindexter, 78 F. Supp. 421 (D. Hawaii 1947). Alley v. Chief, Finance Center, U.S. Army, 167 F. Supp. 303 (S.D. Ind. 1958), defies procedural classification. The plaintiff, an officer who had been sentenced to dismissal, total forfeitures, and ten years imprisonment, apparently attacked only the sentence of dismissal, on the marvelously implausible ground that, the courtmartial having by a lapsits linguae sentenced him to be "dishonorably discharged," the proper form for an enlisted man, neither the court nor the convening authority could thereafter correct the sentence to "dismissal," the proper form for an officer; he sought an order requiring the defendant to disburse to him all of his pay and allowances for the period subsequent to the allegedly invalid dismissal. The court, treating this idiosyncratic piece of pleading as a petition for a writ of mandamus, held that it had no jurisdiction to grant such relief. 
ber of courts have cited such failure as a reason, usually of the "furthermore" variety, for the rejection of various claims of unfairness-including one that the appointed defense counsel was incompetent or indifferent.106 Assuming the truth of an assertion that appointed defense counsel was indifferent or incompetent, it seems quixotic to refuse to hear it because that counsel failed to urge upon the military authorities his own stupidity, ignorance, or laziness.

This claim that the petitioner's defense was of such low calibre as to amount to a denial of his constitutional and statutory rights to the assistance of counsel seems to be the favorite allegation. ${ }^{107}$ Most of the other claims familiar in civilian habeas corpus petitions are also plentiful in the military variety, along with a few that seem to be peculiar to the soldiers. A random sampling reveals allegations that rights under the constitution and/or the Uniform Code were violated by the admission of coerced confessions, ${ }^{108}$ by errors in the Law Officer's instructions on the law ${ }^{109}$ and rulings on evidence, ${ }^{110}$ by conviction upon insufficient evidence, ${ }^{111}$ by denial

106. E.g., Kubel v. Minton, 275 F.2d 789 (4th Cir. 1960); McKinney v. Warden, 273 F.2d 643 (10th Cir. 1959), cert. denied, 363 U.S. 816 (1960); Bennett v. Davis, 267 F.2d 15 (10th Cir. 1959); Thomas v. Davis, 249 F.2d 232 (10th Cir. 1957); Suttles v. Davis, 215 F.2d 760 (10th Cir. 1954) ; Casey v. Taylor, No. 2808 H.C., D. Kan., Feb. 29, 1960, aff'd, 281 F.2d 549 (10th Cir. 1960) ; Bennett v. Cox, No. 2951 H.C., June 28, 1960; Bowerman v. Cox, No. 2869 H.C., D. Kan., March 14, 1960; Tillery v. Cox, No. 2863 H.C., D. Kan., March 14, 1960; Wilson v. Wilkinson, 129 F. Supp. 324 (M.D. Pa. 1955) ; Allen v. Wilkinson, 129 F. Supp. 73 (M.D. Pa. 1955). The Government has asserted that the "manifest refusal" language of Burus v. Wilson entails as a necessary corollary a rule that "if an available contention is not asserted within the military appellate structure, it may not thereafter be raised on habeas corpus." Brief for the Respondent, p. 6, Burns v. Looney, No. 2699 H.C., D. Kan., April 13, 1959, aff'd sub nom. Burns v. Taylor, 274 F.2d 141 (10th Cir. 1959).

107. See, e.g., Rushing v. Wilkinson, 272 F.2d 633 (5th Cir. 1959); McKinney v. Warden, supra note 106; Bennett v. Davis, supra note 106; Mitchell v. Swope, 224 F.2d 365 (9th Cir. 1955); Tillery v. Cox, supra note 106; Sweet v. Taylor, 178 F. Supp. 456 (D. Kan. 1959); Day v. Wilson, 155 F. Supp. 469 (D.D.C. 1957) ; Allen v. Wilkinson, supra note 106.

108. E.g., Rushing v. Wilkinson, supra note 107; Thomas v. Davis, 249 F.2d 232 (10th Cir. 1957), cert. denied, 355 U.S. 927 (1958); Dixon v. United States, 237 F.2d 509 (10th Cir. 1956); Suttles v. Davis, 215 F.2d 760 (10th Cir. 1954); Hurt v. Davis, No. 2821 H.C., D. Kan., April 19, 1960.

109. E.g., Day v. Davis, 235 F.2d 379 (10th Cir.), cert. denied, 352 U.S. 881 (1956);

Bowerman v. Cox, No. 2869 H.C., D. Kan., March 14, 1960; Richards v. Cox, 184 F. Supp. 107 (D. Kan. 1960).

110. E.g., Burns v. Taylor, 274 F.2d 141 (10th Cir. 1959); Day v. Davis, stlpra note 109; see Sweet v. Taylor, 178 F. Supp. 456 (D. Kan. 1958).

111. E.g., Bowerman v. Cox, No. 2869 H.C., D. Kan., March 14, 1960; Sweet v. Taylor, supra note 110; Allen v. Wilkinson, 129 F. Supp. 73 (M.D. Pa. 1955). Traditionally, of course, district courts do not upon petitions for habeas corpus review in either military or civil cases the sufficiency of the evidence of guilt. See Humphrey v. Smith, 336 U.S. 695, 696 (1949). But we have recently learned that a state court conviction which is "totally devoid of evidentiary support" is unconstitutional under the due process clause of the fourteenth amendment. Thompson v. City of Louisville, 362 U.S. 199 (1960). There seems to be no reason why such a conviction should not be equally a denial of due process under the fifth amendment, which of course is applicable to federal proceedings, causing loss of jurisdiction under the principle of Johnson v. Zerbst. See Blevens v. Taylor, No. 2757 H.C., D. Kan., April 27, 1960.

There is a time-honored, although probably apocryphal, legend among Judge Advocates that a court-martial once sentenced an accused in the following form of words: 
of the right of confrontation, ${ }^{112}$ and by conducting the trial in an atmosphere of public hostility and prejudice. ${ }^{113}$ This last is a problem which may be genuine and perplexing when courts-martial sit overseas, because the military authorities, including those who are members of the court, cannot easily exclude from their minds the consideration that exemplary punishment of a culprit may mitigate the evil effect of the crime upon relations between United States forces and local civilians. Likewise I find charges that the incompetence of the interpreter precluded a fair trial ;114 that the petitioner was denied a speedy trial115 or given one speedier than he wanted ${ }^{116}$ that cruel and unusual punishment was inflicted; ${ }^{117}$ that the failure of the President, when confirming a death sentence, to hear the accused in person was a denial of the process to which the latter was entitled under article 70 (a) of the Uniform Code;118 and that the alleged failure of the Court of Military Appeals to follow its own precedents deprived petitioner of the equal protection of the laws. ${ }^{110}$ In view of the prominence of the issue in civilian cases, it may at first blush seem surprising that in only one case since 1953 has a Negro petitioner attacked a conviction on the ground that no Negro sat on the court-martial which tried him. ${ }^{120}$ The explanation is probably the exceedingly simple one that there is in fact no evidence of systematic exclusion of Negroes from the membership of courts-martial.

Could the last allegation be made with any tincture of platusibility, it might compel a court really to consider the meaning of the dictum, so frequent as to be almost a judicial commonplace, that "due process of law for military personnel is what Congress has provided for them in the military

"In view of the fact that there is no evidence of your guilt, you are sentenced to only two years' confinement at hard labor."

112. Easley v. Hunter, 209 F.2d 483 (10th Cir. 1953).

113. Bennett v. Davis, 267 F.2d 15 (10th Cir. 1959); Hurt v. Davis, No. 2821 H.C., D. Kan., April 19, 1960. Each of these courts-martial sat in a foreign country (Austria and Okinawa, respectively), and each involved a brutal crime against one of the local population.

114. Young v. Brucker, No. 2567 H.C., D. Kan., June 2, 1960 (dictum).

115. Day v. Davis, 235 F.2d 379 (10th Cir. 1956). The court thought that a delay of eight months in preparing charges was not unreasonable in view of the chaotic conditions attending the evacuation of Seoul.

116. Mitchell v. Swopc, 224 F.2d 365 (9th Cir. 1955).

117. Easley v. Hunter, 209 F.2d 483 (10th Cir. 1953). This particular complaint was probably not made with any serious hope of success, for the sentence (10 years confinement at hard labor) was well within the maximum allowable for the particular offenses under the Code and the Table of Maximum Punishments promulgated thereunder by the President.

118. Hurt v. Davis, No. 2821 H.C., D. Kan., April 19, 1960; Day v. Wilson, 155 F. Supp. 469 (D.D.C. 1957).

119. Day v. Wilson, supra note 118.

120. Wilson v. Wilkinson, 129 F. Supp. 324 (M.D. Pa. 1955). A similar contention was made with similar lack of success in one other ease, decided some ycars before Burns v. Wilson. See Jackson v. Gough, 170 F.2d 630 (5th Cir. 1948), cert. denied, 336 U.S. 938 (1949). 
hierarchy in courts established according to law."121 This statement appears to mean that if a particular protection cannot be found in the Uniform Code, it does not exist for members of the armed forces. Although the Uniform Code includes most of the explicit guarantees contained in the Bill of Rights, and although the present Court of Military Appeals undoubtedly makes an effort to shape its concept of "military due process" according to the models furnished by the Supreme Court in civilian cases, ${ }^{122}$ the Code falls far short of spelling out all the gloss placed on the due process clause by the Supreme Court. If a conviction by a court-martial from which Negroes had been systematically excluded should ever reach the Supreme Court, I do not think that Justices Black and Douglas would be alone in finding the conviction unconstitutional. Yet it would be hard to point to any provision of the Uniform Code which was violated by such exclusion. In short, it is probably not true that Congress could, if it wanted to, include in its military criminal code a provision plainly inconsistent with the Bill of Rights as interpreted by the Supreme Court; and by the same token it is probably not true that a protection granted by the Bill of Rights, as interpreted by the Supreme Court, is inapplicable to soldiers simply because it is not included in the Uniform Code of Military Justice, as interpreted by the Court of Military Appeals. ${ }^{123}$ The seemingly contrary

121. Mr. Justice Minton, concurring in Burns v. Wilson, 346 U.S. 137, 147 (1953). Compare Reaves v. Ainsworth, 219 U.S. 296, 304 (1911) ("to those in the military or naval service of the United States the military law is due process") ; Burns v. Taylor, 274 F.2d 141, 142 (10th Cir. 1959) ("due process of law as contemplated and vouchsafed by the Uniform Code of Military Justice"); Bennett v. Davis, 267 F.2d 15, 17 (10th Cir. 1959) ("every constitutional safeguard contemplated by the Uniform Code of Military Justice"); White v. Humphrey, 212 F.2d 503, 507 (3d Cir. 1954) ("to members of the military forces due process means the application of the procedure of military law").

122. E.g., United States v. Curtin, 9 U.S.C.M.A. 427, 26 C.M.R. 207 (1958) (reversing conviction for violation of a lawful order by one not shown to have actual knowledge thereof, upon the authority of Lambert v. California, 355 U.S. 225 (1957)); United States v. Jacoby, 11 U.S.C.M.A. 428, 29 C.M.R. 244 (1960). The Court of Military Appeals, though it describes itself as "the Supreme Court of the military justice system," qualifies this supremacy-and perhaps concedes to the Supreme Court a jurisdiction rather broader than that Court has so far been disposed to claim for itself-by adding, "subject only to review by the Supreme Court of the United States on constitutional issues." See United States v. Armbruster, 11 U.S.C.M.A. 596, 598, (1960).

123. Frontal attacks on the constitutionality of the procedural provisions of the Uniform Code and its predecessors have been rare and unsuccessful. In Wade v. Hunter, 336 U.S. 684 (1949), the Supreme Court found it unnecessary to consider the constitutionality of the double jeopardy provision of old Article of War 40 (article 44 of the present Code, 10 U.S.C. \& 844 (1958)), which provided that no proceeding should be deemed to be a "trial" until the reviewing and confirming authorities should have taken final action. One bold petitioner recently asserted that the entire Uniform Code is unconstitutional; the district court thought otherwise. United States ext rel. Watkins v. Vissering, Misc. No. 722, E.D. Va., June 10, 1960. Another petitioner argued that since the Articles of War required a majority of two-thirds of the court for conviction, and of three-quarters for sentencing, at least one member of the court who believed the accused innocent might be compelled to vote upon the sentence, thereby going against his conscience, in violation of his first amendment right to freedom of conscience. But the court had its doubts about the accused's right to vindicate whatever violence may have been done to the conscience of menbers of the court- 
dicta are probably best to be taken as infelicitous efforts to express the very different and entirely sound idea that while the Bill of Rights may in principle apply to soldiers and civilians alike, it does not necessarily give the infantry the same rights that it gives civilians, any more than it confers upon infants the same rights that it does upon adults. The exigencies of the military service may very well justify proceedings which would be unfair if applied to a civilian, or to a soldier in time of peace. ${ }^{124}$

If the Constitution does confer on members of the military some right to a fair trial and does not leave either to Congress or the military authorities the last word in defining that minimum standard of fairness, it follows that the federal courts have on collateral review some power to inquire into the fairness of court-martial proceedings, and that that power ought not to be limited to a mechanical examination of the record to see whether the point was "considered" by the military. At least until the Supreme Court tells us more, the key question is the content that the inferior federal courts will put into the adjectives "full and fair"; do they import nothing more than good faith, or do they require that the conclusions of the military tribunals be defensible?

The dicta of some of the lower courts manifest an inclination to distinguish between the military tribunals' findings of fact and the legal conclusions based on those facts. As phrased by a circuit judge sitting as a district judge in the District of Kansas, "law courts are without jurisdiction to review constitutional questions decided by military courts dependent upon facts which have been found by the military courts, but where the question is whether the admitted facts, as a matter of law, violate constitutional guarantees or due process, the civil court has jurisdiction."125 It must be recognized that the civil courts, when asked to review military determinations, labor under a considerable handicap; military science, including the maintenance of discipline, sometimes entails formidable expertise, and the martial experience, if any, of the ordinary judge is likely to be somewhat obsolete. Considerations such as these, it may be supposed, underlie Mr. Justice Frankfurter's remark that, "[W]e should no doubt attach more weight to the conclusions reached on controversial facts by military appellate courts than to those reached by the highest court of a State."126 Such judicial modesty may be appropriate when the military

martial, and so this inspired effort of the imagination, as ingenious as it was unconvincing, got nowhere. Ex parte Campo, 71 F. Supp. 543 (S.D.N.Y.), aff'd, 165 F.2d 213 (2d Cir. 1947).

124. Cf. Wade v. Hunter, 336 U.S. 684 (1949); Day v. Davis, 235 F.2d 379 (10th Cir.), cert. denied, 352 U.S. 881 (1956).

125. Burns v. Looney, No. 2699 H.C., D. Kan., April 13, 1959, aff'd sub nom. Burns v. Taylor, 274 F.2d 141 (10th Cir. 1959); cf. Rushing v. Wilkinson, 272 F.2d 633, 641 (5th Cir. 1959); Dixon v. United States, 237 F.2d 509, 510 (10th Cir. 1956).

126. Burns v. Wilson, 346 U.S. 137, 149 (1953). But in his dissenting opinion on 
determination really does in one way or another relate to the demands of the tactical situation, as when the petitioner challenges a transfer of charges from one court-martial to another, or a determination that a particular officer is not "available" for service as defense counsel, or a determination that military necessity prevents the personal appearance of a witness, or a delay in bringing the accused to trial in a theater of actual combat. But there seems to be no compelling reason to extend this hesitance to problems that lack any distinctively military flavor, such as whether an accused who was beaten up by the military police has confessed voluntarily or whether the record supports a finding that he was not in fact mishandled. Some recent opinions, particularly in the crucial district of Kansas, ${ }^{127}$ evince a cautious disposition to reason that a military determination that is in the civil court's judgment plainly at odds with the record cannot have been based upon fair consideration. In the words of a senior circuit judge:

It is sometimes stated that if the military reviewing authorities have considered and decided the constitutional question sought to be raised in a habeas corpus case, then the matter is at an end, and the civil court is without jurisdiction. In the court's view, that statement is too broad. In Burns v. Wilson . . . it is stated that 'when a military decision has dealt fully and fairly with an allegation raised in that application, it is not open to a federal civil court to grant the writ simply to reevaluate the evidence.' However, if a careful examination of the record compels a conclusion that there is no evidence to sustain the judgment or that in fact petitioner was not represented by an attorney, or that it must be said that basic constitutional rights were violated, it would seem that a civil court would have jurisdiction to grant relief because under such circumstances it cannot be said that the reviewing military authorities fairly considered these questions. ${ }^{128}$

As a declaration of the rights of military man, this is certainly something less than ringing. But however discreet its phrasing, it may nonetheless

the petition for rehearing, Mr. Justice Frankfurter said that he expressed no opinion "on the weight which should be given by the federal district court on habeas corpus to the findings of the military reviewing authorities." Id. at 850 .

127. Both the United States Disciplinary Barracks and the well known federal penitentiary are located in Leavenworth.

128. Sweet v. Taylor, 178 F. Supp. 456, 458 (D. Kan. 1959) (Huxman, Senior Circuit Judge). Compare Young v. Brucker, No. 2567 H.C., D. Kan., June 2, 1958 ("The court does have jurisdiction to examine the record to see whether there is basis in fact for the findings by the military court."). The dicta quoted from the Sweet case are somewhat difficult to reconcile with the attitude to military findings of fact which the same judge had six months previously displayed in Burns v. Looney, No. 2699 H.C., D. Kan., April 13, 1959, aff'd sıb nom. Burns v. Taylor, 274 F.2d 141 (10th Cir. 1959). Another court has qualified the proposition that a civil court should not reevaluate the evidence bearing on the voluntariness of a confession by the phrase, "at least when the military court's evaluation is not so unreasonable as to shock one's-sense of justice." See Rushing v. Wilkinson, 272 F.2d 633, 641 (5th Cir. 1959); cf. Richards v. Cox, 184 F. Supp. 107, 108 (D. Kan. 1960) ("it is only when the overall picture presented by the record is offensive to the concepts of common justice and fairness that a law court may intervene"). 
contain the seeds of a collateral review of the verdicts of courts-martial comparable in breadth to that which has developed for cases involving state prisoners since Johnson v. Zerbst was decided; many a majestic legal oak has grown from an acorn no larger than this. True, the acorn still lies dormant in the ground; it is a stubborn fact that in no case decided after Burns v. Wilson has a soldier petitioner persuaded a court to grant the writ. We cannot say in what circumstances a district court would find such unfairness as to nullify the sentence of the military tribunal. It is at least clear that the unfairness will have to have been pretty blatant before the courts will grant what they evidently still consider an extraordinary and radical remedy. It has been said that neither errors in the Law Officer's instructions ${ }^{129}$ nor prejudicial comment by the prosecutor ${ }^{130}$ are enough to rouse a civil court to action. The admission of evidence that the Supreme Court has held inadmissible in federal criminal trials has also been held to be "common and ordinary error," beyond the civil court's power to review ${ }^{131}$-although the court did suggest that the result might be different if instead of a single error, however damaging, the errors during a military trial were "so numerous, glaring and persistent as to be offensive to our concept of a fair trial and thus constitute a denial of due process"-which sounds very much like a return to the philosophy of Hicks $v$. Hiatt. ${ }^{132}$ More, the court hinted at the possibility that a "wilful and intentional" admission of such testimony, that is, a wilful and intentional failure to ad-

129. Kubel v. Minton, 275 F.2d 789, 791 (4th Cir. 1959); Day v. Davis, 235 F.2d 379, 385 (10th Cir.), cert. denied, 352 U.S. 881 (1956). For this purpose it is not unfair to analogize the Law Officer's instructions to a civil court's charge to the jury. See Uniform Code of Military Justice, art. 51(c), 10 U.S.C. \& 851(c) (1958); MANUAL FOR Courts-Martial United States II 73 (1951).

130. Thomas v. Davis, 249 F.2d 232, 235 (10th Cir. 1957), cert. denied, 355 U.S. 927 (1958).

131. Burns v. Looney, No. 2699 H.C., D. Kan., April 13, 1959, aff'd sub nom. Burns v. Taylor, 274 F.2d 141 (10th Cir. 1959). In the particular case the court-martial and the military reviewing authorities, including the Court of Military Appeals, had permitted the wife of the accused to testify against him, over his objection. The Court of Military Appeals denied the petition for grant of review. United States v. Burns, 6 U.S.C.M.A. 834 (1955). Thereafter the Supreme Court held that it was error to admit such evidence in a criminal trial in a federal court. Hawkins v. United States, 358 U.S. 754 (1958). The Supreme Court's decision in the Hawkins case was not an adjudication that the admission of the wife's testimony constituted a denial of constitutional due process, but simply an exercise of its power to supervise the administration of criminal justice in the federal courts, a power that does not extend to courtsmartial. See Burns v. Wilson, 346 U.S. 137, $145 \mathrm{n} .12$ (1953). But the ruling of the military tribunals was nonetheless wrong, in the light of hindsight, for article 36 (a) of the Uniform Code, 10 U.S.C. \& 836(a) (1958), directs that the President shall, so far as he deems practicable, and so far as is not inconsistent with other provisions of the Code, prescribe for courts-martial "the rules of evidence generally recognized in the trial of criminal cases in the United States district courts. ..." The Mantlal for CottrtsMartial accordingly provides that courts-martial shall apply the federal courts' rules of evidence, "so far as not otherwise prescribed," and there is nothing in the Manual that would have sanctioned the wife's testimony in the circumstances of the case, the wife not being the person injured by the husband's offense. MANUAL Fon Courts-Martial UNITED STATES III 137, 148e (1951).

132. See text accompanying notes 6-7 supra. 
here to the rules of evidence recognized in the federal courts, might be a denial of due process, even though the Supreme Court's rulings were no more than an exercise of its power to supervise federal criminal justice and not a determination that the exclusion of certain testimony was essential to due process. ${ }^{133}$ It seems clear, reading the opinion as a whole, that the court did not suppose that errors in the admission or rejection of evidence could not be a basis for finding a denial of due process, but simply that the garden variety of error, such as courts daily commit, will not do. Similarly, the Law Officer's instructions or the Trial Counsel's inflammatory rhetoric might plumb such depths of ignorance or impropriety as to cause a habeas corpus court to sit up and start talking in terms of fundamental unfairness, or even of shock to its sense of justice.

None of these cases offers bright hopes to the military prisoner as he sits of evenings in his cell teaching himself the elements of constitutional law and practicing the composition of petitions in forma pauperis. One recent case, indeed, seems restrictive even by the traditional standard, for it appears to hold that the military's construction of the law is no less impregnable than its findings of fact, even when the court-martial's jurisdiction over the offense itself would seem to turn upon the reading of such statutory language as "in time of war."134 No doubt there are situations in which the military's interpretation of statutory language is entitled to special weight, ${ }^{135}$ but it has no obvious special competence to make the

133. See note 131 supra. The problem would be more difficult if the President, finding impracticable the application to courts-martial of a federal rule of evidence, should prescribe a different rule in the Manual, and still more difficult if the Uniform Code itself should prescribe a different rule. The former problem was actually presented to the Court of Military Appeals in United States v. Haynes, 9 U.S.C.M.A. 792, 795-96, 27 C.M.R. 60, 63-64 (1958), which held "incorrect," as in conflict with Nardone v. United States, 308 U.S. 338 (1939), a provision of the Manual permitting the introduction of evidence obtained indirectly by means of an inadmissible confession.

134. Fischer v. Ruffner, 277 F.2d 756 (5th Cir. 1960). The accused had deserted the Army in 1953, during the Korean hostilities, but was not brought before a courtmartial until 1959. Article 43 of the Uniform Code, 10 U.S.C. \& 843 (1958), permits trial for wartime desertion without limitation of time, but imposes a three-year limitation on trial for desertion in time of peace. The accused contended that the Korean shooting was not "war," so that his trial was barred. The court, considering that any error by the military in applying the language of article 43 to the Korean conflict was an "ordinary" error of law, not affecting jurisdiction, refused to review the Army's construction. No mention was made of a 1959 decision of the Supreme Court granting the writ on the ground that the military tribunals had erred in holding that June 10, 1949, was not "in time of peace" for the purposes of former Article of War 92, which deprived courts-martial of jurisdiction to try cases of murder or rape committed in the United States in time of peace. Lee v. Madigan, 358 U.S. 228 (1959).

135. Thus, the military authorities have traditionally been accorded wide, although not unlimited, discretion to decide what sins are "conduct of a nature to bring discredit upon the armed forces" or "disorders and neglects to the prejudice of good order and discipline in the armed forces" and therefore within the denunciation of the general, or catchall, article. Compare Blevens v. Taylor, No. 2757 H.C., D. Kan., April 27, 1960 , in which the court held that while a court-martial is without jurisdiction to try a violation of the Smith Act, 18 U.S.C. \& 2385 (1958), a soldier who defected to the East German government and participated in its propaganda activities was clearly guilty of "conduct of a nature to bring discredit upon the armed forces," in violation 
essentially political distinction between a "war" and a mere "police action."

The most that can be said-and it may prove to be a good deal-is that since and despite Burns v. Wilson the inferior federal courts have tended to reject the more extreme claims of the Government and to include in their opinions dicta that at least preserve their freedom of maneuver; conversely, they have on the whole been careful to limit their actual holdings to the exact facts before them-facts that usually would not have justified collateral attack upon the verdict of a State court. Nothing in these cases would preclude collateral relief if a sufficiently unpleasant set of facts were alleged and established.

\section{Conclusion}

I am of the opinion that this gradual edging away from the orthodox doctrine and toward a practical homologizing of military and civil sentences for the purposes of collateral review is very much to be desired. It is to be hoped that the "manifest refusal" language will be allowed quietly to fade away and that increasing stress will be put upon the words "fuil and fair." I come to this opinion partly for the reason I have already given, that the best guarantee of fundamental fairness in military trials, in all circumstances, is the existence of a power, wholly independent of the military organization, to enforce such fairness; partly because it is very unlikely that the recognition of a power of collateral review equivalent to that which is exercised over the criminal justice of the States would actually lead to a different result in an appreciable number of cases ${ }^{136}$ or otherwise seriously hamper military discipline, except in circumstances in which it may need a little hampering; partly because there is something irrational in what Mr. Justice Frankfurter describes as "the principle that a conviction by a constitutional court which lacked due process is open to attack by habeas corpus while an identically defective conviction when rendered by an ad hoc military tribunal is invulnerable."137 But the main reason for my conviction that the civil courts should draw as little distinction as possible between military and civil tribunals and between soldiers and other citizens, is simply that, if there ever was a time when the Army could rationally be described as a "separate community" with a separate system of government, ${ }^{138}$ that time is long past. Most male citizens of the United

of article 134 of the Uniform Code, 10 U.S.C. \& 934 (1958). See Hagan, The Gencral Article-Elemental Confusion, Military L. Rev., Oct. 1960, p. 60, at p. 63.

136. "[W]ith the Court of Military Appeals reversing the worst cases, there will not be many instances where a military accused who has exhausted the involved process of the Uniform Code will find any genuine necessity for resorting to collateral review in a federal district court." Wiener, Courts-Martial and the Bill of Rights: The Original Practice, 72 HaRv. L. REv. 266, 302 (1958).

137. Separate opinion in Burns v. Wilson, 346 U.S. 844, 851 (1953).

138. See Carter v. McClaughry, 183 U.S. 365, 389 (1902). Mr. Chief Justice 
States (and a fair number of the female ones) have a relation to the armed forces as direct and personal as that of a citizen of Pericles' Athens or the Roman Republic in the days of Cato the Censor. My objection to the "separate community" idea is not simply that it does not square with the facts. On the basis of the experience of many nations in many times, I believe that concept to be actually pernicious, as is any way of thinking which tends to make the armed services an enclave of the national polity whose inhabitants are of other caste than the rest.

The United States has had no Dreyfus case. One reason is that in fact, and despite their categorical pronouncements, it is unlikely that the constitutional courts of the United States, if actually confronted with such a record, would have taken water and washed their hands. Obviously, there have got to be major differences between soldiers and civilians, including differences in their respective systems of criminal justice. But our policy should not be to maximize these differences so far as that can be done without outraging the courts' sense of justice, but rather to minimize them so far as that can be done without impairing military efficiency.

Fuller, who had never been a soldier, thought this apartheid "essential to the maintenance of that discipline which renders the Army efficient in war and morally progressive in peace. ..." Ibid. 